\title{
Structural and Stereochemical Studies of Hydroxyanthraquinone Derivatives from the Endophytic Fungus Coniothyrium sp
}

\author{
PENG SUN,${ }^{1, \dagger}$ JUAN HUO,${ }^{1, \dagger}$ TIBOR KURTÁN, ${ }^{2}$ ATTILA MÁNDI, ${ }^{2}$ SÁNDOR ANTUS, ${ }^{2}$ HUA TANG, ${ }^{1}$ SIEGFRIED DRAEGER, ${ }^{3}$ \\ BARBARA SCHULZ, ${ }^{3}$ HIDAYAT HUSSAIN, ${ }^{4}$ KARSTEN KROHN,${ }^{4}$ WEIHUA PAN,${ }^{5}$ YANGHUA YI, ${ }^{1 *}$ AND WEN ZHANG ${ }^{1 *}$ \\ ${ }^{1}$ Research Center for Marine Drugs, School of Pharmacy, Second Military Medical University, 325 Guo-He Road, Shanghai 200433 P. R. China \\ ${ }^{2}$ Department of Organic Chemistry, University of Debrecen, P.O.B.: 20, H-4010 Debrecen Hungary \\ ${ }^{3}$ Institut für Mikrobiologie, Technische Universität Braunschweig, Spielmannstraße 7, 31806 Braunschweig Germany \\ ${ }^{4}$ Department Chemie, Universität Paderborn, Warburger Straße 100, 33098 Paderborn Germany \\ ${ }^{5}$ Shanghai Key Laboratory of Molecular Medical Mycology, Institute of Dermatology and Mycology, Changzheng Hospital, Second Military Medical \\ University, Shanghai, 200003 P. R. China
}

\begin{abstract}
Four known hydroxyanthraquinones (1-4) together with four new derivatives having a tetralone moiety, namely coniothyrinones A-D (5-8), were isolated from the culture of Coniothyrium sp., an endophytic fungus isolated from Salsola oppostifolia from Gomera in the Canary Islands. The structures of the new compounds were elucidated by detailed spectroscopic analysis and comparison with reported data. The absolute configurations of coniothyrinones A (5), B (6), and D (8) were determined by TDDFT calculations of CD spectra, allowing the determination of the absolute configuration of coniothyrinone C (7) as well. Coniothyrinones A (5), B (6), and D (8) could be used as ECD reference compounds in the determination of absolute configuration for related tetralone derivatives. This is the first report of anthraquinones and derivatives from an isolate of the genus Coniothyrium sp. These compounds showed inhibitory effects against the fungus Microbotryum violaceum, the alga Chlorella fusca, and the bacteria Escherichia coli and Bacillus megaterium. Chirality 00:000-000, 2012. (c) 2012 Wiley Periodicals, Inc.
\end{abstract}

KEY WORDS: anthraquinone derivatives; absolute configuration; Coniothyrium sp., coniothyrinones; tetralone; TDDFT ECD calculation

\section{INTRODUCTION}

Fungi of the Coniothyrium genus are widely distributed in nature, occurring frequently as endophytes and plant pathogens. In the course of our ongoing investigations to search for new biologically active secondary metabolites from fungi, we have repeatedly analyzed the culture extracts of Coniothyrium species, a very creative genus with respect to secondary metabolism. ${ }^{1}$ Isolation and structural elucidation afforded a series of naphthalene derivatives, including palmarumycins, ${ }^{2-4}$ nitronaphthalenes, ${ }^{5}$ and $\alpha$-methylene- $\gamma$-lactone derivatives belonging to the group of massarilactones. 6 .7 These metabolites demonstrated antifungal, ${ }^{3,5}$ antibacterial, ${ }^{3,5}$ and antialgal activities $^{3}$ in bioassays in vitro. In addition, several benzofuranones and derivatives have also been isolated from the fungus, showing similar antimicrobial activities. ${ }^{8,9}$

In connection with our ongoing screening for new bioactive metabolites from fungi, ${ }^{10-14}$ we reinvestigated another endophytic Coniothyrium sp., isolated from the plant Salsola oppostifolia, growing in Gomera, Spain. The crude ethyl acetate extract of the biomalt agar culture showed pronounced antifungal activity against Microbotryum violaceum. Fractionation of the extract led to the isolation of four known hydroxyanthraquinones (1-4), together with four new analogues: coniothyrinones A-D (5-8). This is the first report of anthraquinones and their derivatives from an isolate of the genus Coniothyrium. The absolute configurations of coniothyrinones A (5), B (6), and D (8) were determined on the basis of TDDFT calculations of ECD spectra, allowing the determination of absolute configuration of coniothyrinones C (7). Herein we report the isolation, structural elucidation, and bioactivities of these compounds.

\section{MATERIALS AND METHODS General and Instrumentation}

Commercial silica gel (Yantai, P. R. China, 200-300; 400-500 mesh) was used for column chromatography. Precoated silica gel plates (Yantai, P. R. China, HSGF-254) were used for analytical thin-layer chromatography (TLC). Spots were detected on TLC under UV or by heating after spraying with $0.5 \mathrm{ml}$ of anisaldehyde in $50 \mathrm{ml}$ of HOAc and $1 \mathrm{ml}$ of $\mathrm{H}_{2} \mathrm{SO}_{4}$. The NMR spectra were recorded at $293 \mathrm{~K}$. Chemical shifts were reported in parts per million ( $\delta$ ), coupling constant $(\delta)$ in $\mathrm{Hz} .{ }^{1} \mathrm{H}$ and ${ }^{13} \mathrm{C}$ NMR assignments were supported by ${ }^{1} \mathrm{H}-{ }^{1} \mathrm{H}$ COSY, HMQC, and HMBC experiments. The following abbreviations are used to describe spin multiplicity: $\mathrm{s}=$ singlet, $\mathrm{d}=$ doublet, $\mathrm{t}=$ triplet, $\mathrm{q}=$ quartet, $\mathrm{m}=$ multiplet, $b r s=$ broad singlet, $\mathrm{dd}=$ doublet of doublets, $\mathrm{ddd}=$ doublet of doublets of doublets, $\mathrm{dt}=$ doublet of triplets, $\mathrm{qd}=$ quartet of doublets, $\mathrm{ov}=$ overlapped signals. Optical rotations were measured in $\mathrm{CHCl}_{3}$ on an Autopol IV polarimeter at the sodium D line $(590 \mathrm{~nm})$. Infrared spectra were recorded in thin polymer films on a Nexus 470 FT-IR spectrophotometer; peaks are reported in $\mathrm{cm}^{-1}$. Melting points were determined on an XT5XMT micro melting point apparatus and are uncorrected. UV absorption spectra were recorded on a Varian Cary $100 \mathrm{UV}$-Vis spectrophotometer; wavelengths are reported in $\mathrm{nm}$. Circular dichroism (CD) spectra were recorded on a Jasco-715 spectropolarimeter. The mass spectra and high resolution mass spectra were performed on a Finnigan-MAT-95 mass spectrometer and a Q-TOF Micro mass spectrometer. Semi-preparative

\footnotetext{
Additional Supporting Information may be found in the online version of this article. *Correspondence to: Wen Zhang or Yanghua Yi, Research Center for Marine Drugs, School of Pharmacy, Second Military Medical University, 325 Guo-He Road, Shanghai 200433, P. R. China. E-mail: wenzhang1968@163.com; E-mail: yiyanghua@126.com

Received for publication 10 April 2012; Accepted 24 September 2012

DOI: $10.1002 /$ chir. 22128

Published online in Wiley Online Library

(wileyonlinelibrary.com).
} 
RP-HPLC was performed on an Agilent1100 system equipped with a refractive index detector using a YMC Pack ODS-A column (particle size $5 \mu \mathrm{m}, 250 \times 10 \mathrm{~mm})$.

\section{Culture, Extraction, and Isolation}

The endophytic fungus Coniothyrium sp., internal strain No. zw86, was isolated from the plant Salsola oppostifolia, growing on Gomera, in the Canary Islands. It was cultivated on 121 of $5 \% w / v$ biomalt solid agar medium at room temperature for 28 days. ${ }^{15-17}$ The culture was extracted with ethyl acetate to afford $4.6 \mathrm{~g}$ of a residue after removal of the solvent under reduced pressure. The extract was subjected to column chromatography (CC) on silica gel, eluted with a gradient of petroleum ether in trichloromethane $(100: 1,100: 10,100: 20,50: 50,20: 80,1: 100)$ to give 16 subfractions. Fractions 1 and 2 were first purified on silica gel CC (200-300 mesh, $n$-hexane/EtOAc, 100:1), and then eluted with $n$-hexane/ $\mathrm{EtOAc} / \mathrm{Et}_{3} \mathrm{~N}$ (50:1:0.25) on silica gel CC (200-300 mesh) to yield pure $\mathbf{1}$ $(1.0 \mathrm{~g})$. Fraction 4 was first purified on silica gel CC (200-300 mesh, $n$-hexane $/ \mathrm{CH}_{2} \mathrm{Cl}_{2}, 5: 1$ ), and then eluted ( $n$-hexane/CHCl $3 / \mathrm{MeOH}, 2: 1: 1$ ) on Sephadex LH-20 column. Purification of the resulted subfractions on RP-HPLC afforded $2(1.0 \mathrm{mg}, 13.0 \mathrm{~min})$ and $3(1.0 \mathrm{mg}, 14.0 \mathrm{~min})$ with an eluent of $\mathrm{MeOH} / \mathrm{H}_{2} \mathrm{O}(93: 7,1.0 \mathrm{ml} / \mathrm{min})$, and $4(3.0 \mathrm{mg}, 12.0 \mathrm{~min})$ with an eluent of $\mathrm{MeOH} / \mathrm{H}_{2} \mathrm{O}(95: 5,1.0 \mathrm{ml} / \mathrm{min})$. Fraction 5 was first subjected to a silica gel CC (200-300 mesh, $\left.\mathrm{CH}_{2} \mathrm{Cl}_{2} / \mathrm{MeOH} 100: 1\right)$, and then purified by RP-HPLC $\left(\mathrm{MeOH} / \mathrm{H}_{2} \mathrm{O}, 75: 25 ; 1.5 \mathrm{ml} / \mathrm{min}\right)$ to afford $6(2.0 \mathrm{mg}$, $14.5 \mathrm{~min})$. Fractions 11 and 13 were first purified on silica gel CCs (200-300 mesh, $\mathrm{CH}_{2} \mathrm{Cl}_{2}$ /EtOAc, 10:1), followed by silica gel CCs (10-40 $\left.\mu \mathrm{m}, \mathrm{CH}_{2} \mathrm{Cl}_{2} / \mathrm{MeOH}, 100: 1\right)$. The subsequent RP-HPLC purification gave $7(1.5 \mathrm{mg}, 19 \mathrm{~min})$ and $\mathbf{8}(2.0 \mathrm{mg}, 14 \mathrm{~min})$ from fraction 11 with an eluent of $\mathrm{MeOH} / \mathrm{H}_{2} \mathrm{O}(60: 40,1.5 \mathrm{ml} / \mathrm{min})$, and $\mathbf{5}(2.0 \mathrm{mg}, 16.5 \mathrm{~min})$ from fraction 13 with an eluent of $\mathrm{MeOH} / \mathrm{H}_{2} \mathrm{O}(70: 30,1.0 \mathrm{ml} / \mathrm{min})$.

Pachybasin (1). Yellow powder; m.p. $175-176{ }^{\circ}$ C; ${ }^{1} \mathrm{H}$ NMR $\left(500 \mathrm{MHz}, \mathrm{CDCl}_{3}\right): \delta=7.10(\mathrm{~s}, 1 \mathrm{H}, \mathrm{H}-2), 7.64(\mathrm{~s}, 1 \mathrm{H}, \mathrm{H}-4), 8.29$ (ov, $2 \mathrm{H}, \mathrm{H}-5 / \mathrm{H}-8$ ), 7.79 (ov, $2 \mathrm{H}, \mathrm{H}-6 / \mathrm{H}-7$ ), 12.56 (s, $1 \mathrm{H}, 1-\mathrm{OH}$ ), 2.46 (s, $3 \mathrm{H}, \mathrm{H}-11) \mathrm{ppm} ;{ }^{13} \mathrm{C}$ NMR $\left(125 \mathrm{MHz}, \mathrm{CDCl}_{3}\right): \delta=162.8(\mathrm{C}, \mathrm{C}-1)$, 124.1 (CH, C-2), 148.6 (C, C-3), 120.8 (CH, C-4), 133.7 (C, C-4a), 127.4 (CH, C-5), $134.4(\mathrm{CH}, \mathrm{C}-6), 134.2(\mathrm{CH}, \mathrm{C}-7), 126.8$ (CH, C-8), 133.2 (C, C-8a), 188.1 (C, C-9), 114.1 (C, C-9a), 182.7 (C, C-10), 133.4 (C, C-10a), $22.2\left(\mathrm{CH}_{3}, \mathrm{C}-11\right) \mathrm{ppm}$; EIMS $\mathrm{m} / z 238[\mathrm{M}]^{+}(100), 223$ (14), 210 (18), 181 (33), 165 (9), 152 (25), 105 (12), 76 (18).

1,7-dihydroxy-3-methyl-9,10-anthraquinone (2). Yellow powder; m.p. $263-265^{\circ} \mathrm{C} ;{ }^{1} \mathrm{H}$ NMR $\left(500 \mathrm{MHz}\right.$, Acetone- $\left.\mathrm{d}_{6}\right)$ ) $\delta=7.12(\mathrm{~s}, 1 \mathrm{H}$, H-2), 7.57 (s, $1 \mathrm{H}, \mathrm{H}-4), 8.12$ (d, $J=10.0,1 \mathrm{H}, \mathrm{H}-5), 7.30$ (d, $J=10.0$, $1 \mathrm{H}, \mathrm{H}-6$ ), 7.65 (s, 1 H, H-8), 12.50 (brs, $1 \mathrm{H}, 1-\mathrm{OH}$ ), 2.47 (s, $3 \mathrm{H}, \mathrm{H}-$ 11) ppm; ${ }^{13} \mathrm{C}$ NMR (125 MHz, [D]6Acetone): $\delta=163.2$ (C, C-1), 123.7 (CH, C-2), 149.7 (C, C-3), 120.9 (CH, C-4), 134.6 (C, C-4a), 130.8 (CH, C-5), 122.8 (CH, C-6), 164.7 (C, C-7), $113.2(\mathrm{CH}, \mathrm{C}-8)$, 136.4 (C, C-8a), 189.3 (C, C-9), 115.1 (C, C-9a), 181.5 (C, C-10), 126.6 (C, C-10a), $22.1\left(\mathrm{CH}_{3}, \mathrm{C}-11\right)$ ppm; EIMS $\mathrm{m} / z 254[\mathrm{M}]^{+}(100), 239$ (17), 226 (24), 197 (25), 181 (11), 169 (14), 141 (13), 115 (16).

Phomarin (3). Yellow powder; m.p. $264-266{ }^{\circ} \mathrm{C} ;{ }^{1} \mathrm{H} \mathrm{NMR} \mathrm{(500} \mathrm{MHz,}$ [D]6Acetone): $\delta=7.13(\mathrm{~s}, 1 \mathrm{H}, \mathrm{H}-2), 7.57 \quad(\mathrm{~s}, 1 \mathrm{H}, \mathrm{H}-4), 7.60$ (d, $J=2.5 \mathrm{~Hz}, 1 \mathrm{H}, \mathrm{H}-5), 7.28$ (dd, $J=10.0,2.5 \mathrm{~Hz}, 1 \mathrm{H}, \mathrm{H}-7), 8.18$ (d, $J=10.0 \mathrm{~Hz}, 1 \mathrm{H}, \mathrm{H}-8), 12.89$ (brs, $1 \mathrm{H}, 1-\mathrm{OH}), 2.47$ (s, $3 \mathrm{H}, \mathrm{H}-11$ ) $\mathrm{ppm} ;{ }^{13} \mathrm{C}$ NMR $\left(125 \mathrm{MHz}\right.$, Acetone- $\left.\mathrm{d}_{6}\right): \delta=163.2$ (C, C-1), 124.5 (CH, C-2), 148.9 (C, C-3), 120.9 (CH, C-4), 134.5 (C, C-4a), 113.7 (CH, C-5), 165.1 (C, C-6), 122.3 (CH, C-7), 130.5 (CH, C-8), 126.0 (C, C-8a), 188.2 (C, C-9), 114.8 (C, C-9a), 183.1 (C, C-10), 136.9 (C, C-10a), $22.0\left(\mathrm{CH}_{3}, \mathrm{C}-11\right)$ ppm; EIMS $m / z 254[M]^{+}$(100), 239 (8), 226 (23), 197 (29), 181 (13), 169 (13), 141 (15), 115 (18).

1-Hydroxy-3-hydroxymethyl-9,10-anthraquinone (4). Yellow powder; m.p. $264-266{ }^{\circ} \mathrm{C}$; ${ }^{1} \mathrm{H}$ NMR (500 MHz, [D]6Acetone): $\delta=7.33(\mathrm{~s}, 1 \mathrm{H}, \mathrm{H}-2), 7.77$ (s, $1 \mathrm{H}, \mathrm{H}-4), 8.23$ (m, 1H, H-5), 7.92 (ov, $2 \mathrm{H}, \mathrm{H}-6 / \mathrm{H}-7$ ), 8.29 (m, 1 H, H-8), 12.59 (s, 1 H, 1-OH), 4.77 (s, 3 H, H-11) ppm; ${ }^{13} \mathrm{C}$ NMR (125 MHz, Acetone- $\left.\mathrm{d}_{6}\right): \delta=163.7$ (C, C-1), 121.3 (CH, C-2), 154.2 (C, C-3), 117.8 (CH, C-4), 134.6 (C, C-4a), 127.9 (CH, C-5), 135.7 (CH, C-6), $135.2(\mathrm{CH}, \mathrm{C}-7), 127.5(\mathrm{CH}, \mathrm{C}-8)$, 134.2 (C, C-8a), 189.2 (C, C-9), 115.6 (C, C-9a), 182.8 (C, C-10), 134.4 Chirality DOI 10.1002/chir
(C, C-10a), $63.74\left(\mathrm{CH}_{2}, \mathrm{C}-11\right)$ ppm; EIMS $m / z 254[M]^{+}$(100), 225 (93), 197 (27), 180 (16), 152 (28), 139 (33), 115 (23), 105 (17).

Coniothyrinone $\boldsymbol{A}$ (5). Yellow powder; m.p. $238-240{ }^{\circ} \mathrm{C} ;[\alpha] 20 \mathrm{D}=-50$ $(c 0.18, \mathrm{MeOH}) ; \mathrm{CD}\left(\mathrm{CH}_{3} \mathrm{CN}, c 3.6 \times 10^{-4}\right): \lambda_{\max }(\varepsilon)=339(-3.46), 326$ (-3.69), 268 (-8.35), 229 (-5.02), 213sh (10.97), 201 (15.16) nm; IR (film): $v_{\max }=3290,2921,2854,1629,1567,1046,849,767 \mathrm{~cm}^{-1}$; UV $(\mathrm{MeOH})$ : $\lambda_{\max }(\log \varepsilon)=222(4.20), 244$ (3.92), 271 (4.18), 309 (3.59), 336 (3.74) $\mathrm{nm} ;{ }^{1} \mathrm{H}$ NMR and ${ }^{13} \mathrm{C}$ NMR in [D]6DMSO, see Table 1; HREIMS: T1 $m / z$ calcd for $\mathrm{C}_{15} \mathrm{H}_{16} \mathrm{O}_{5}: 276.0998$; found $276.1000[M]^{+}$.

Coniothyrinone $\boldsymbol{B}(\boldsymbol{6})$. Colorless powder; m.p. $237-239{ }^{\circ} \mathrm{C}$; $[\alpha] 20$ $\mathrm{D}=-4(c \quad 0.12, \mathrm{MeOH}) ; \mathrm{CD}\left(\mathrm{CH}_{3} \mathrm{CN}, c 0.76 \times 10^{-4}\right): \lambda_{\max }(\varepsilon)=337$ (-2.51), 325sh (-2.29), 293sh (0.49), 267 (10.65), 234 (3.30), 216 (-23.77), positive CE below $200 \mathrm{~nm}$; IR (film): $v_{\max }=3313$, 2924, 2851, 1635, 1574, 1049, 850, $784 \mathrm{~cm}^{-1}$; UV $(\mathrm{MeOH}): \lambda_{\max }(\log \varepsilon)=207$ (3.62), 220 (4.30), 243 (3.64), 267 (4.07), 292 (3.22), 331 (3.61) nm; ${ }^{1} \mathrm{H}$ NMR and ${ }^{13} \mathrm{C}$ NMR in [D]6DMSO, see Table 1; HRESIMS: $\mathrm{m} / z$ calcd for $\mathrm{C}_{15} \mathrm{H}_{17} \mathrm{O}_{4}: 261.1127$; found $261.1127[M-\mathrm{H}]^{+}$.

TABLE 1. NMR data for coniothyrinones $A$ and $B(5,6)$ in [D] 6DMSO

\begin{tabular}{|c|c|c|c|c|}
\hline \multirow[b]{2}{*}{ No. } & 5 & & \multicolumn{2}{|l|}{6} \\
\hline & $\delta_{\mathrm{H}}, \mathrm{m}, J$ in $\mathrm{Hz}$ & $\delta_{\mathrm{C}}, \mathrm{m}$ & $\delta_{\mathrm{H}}, \mathrm{m}, J$ in $\mathrm{Hz}$ & $\delta_{\mathrm{C}}, \mathrm{m}$ \\
\hline 1 & & 163.3, s & & $163.4, \mathrm{~s}$ \\
\hline 2 & & 118.3, d & $6.63, \mathrm{~s}$ & $116.6, \mathrm{~d}$ \\
\hline & & $150.0, \mathrm{~s}$ & & 148.7, s \\
\hline & & 122.6, d & $7.10, \mathrm{~s}$ & $118.2, \mathrm{~d}$ \\
\hline $4 a$ & & $146.2, \mathrm{~s}$ & & $149.9, \mathrm{~s}$ \\
\hline $5 \alpha$ & $567 \mathrm{~s}$ & 128.8, d & 2.67, m & $39.8, \mathrm{t}$ \\
\hline $5 \beta$ & & & $1.31, \mathrm{q}, 11.8$ & \\
\hline 6 & 5.67. s & 132.1, d & $3.55, \mathrm{~m}$ & $69.5, \mathrm{~d}$ \\
\hline $7 \alpha$ & 4.18 , br s & 73.6, d & $1.33, \mathrm{~m}$ & $35.4, \mathrm{t}$ \\
\hline $7 \beta$ & & & $2.07, \mathrm{~m}$ & \\
\hline $8 \alpha$ & & $74.5, \mathrm{t}$ & $2.40, \mathrm{ov}$ & $24.9, \mathrm{t}$ \\
\hline $8 \beta$ & $\begin{array}{l}\text { 4.05, dd, } 10.3 \text {, } \\
3.0\end{array}$ & & 1.35 , ov & \\
\hline $8 a$ & $\begin{array}{l}3.29 \text {, dd, } 10.3 \text {, } \\
9.2\end{array}$ & $45.6, \mathrm{~d}$ & 2.37, ov & 49.7, d \\
\hline 9 & & $208.8, \mathrm{~s}$ & & $206.1, \mathrm{~s}$ \\
\hline $9 \mathrm{a}$ & & $113.9, \mathrm{~s}$ & & $113.8, \mathrm{~s}$ \\
\hline 10 & $85 \mathrm{hrc}$ & $69.3, \mathrm{~d}$ & $4.54, \mathrm{dd}, 11.8,8.0$ & $72.4, \mathrm{~d}$ \\
\hline $10 \mathrm{a}$ & $\begin{array}{l}4.85, \text { Dr s } \\
2.97, \mathrm{dt}, 9.2 \text {, } \\
2.6\end{array}$ & $44.2, \mathrm{~d}$ & $1.85, \mathrm{qd}, 11.8,3.2$ & $46.9, \mathrm{~d}$ \\
\hline 11 & $2.34, \mathrm{~s}$ & $22.0, \mathrm{q}$ & $2.34, \mathrm{~s}$ & $22.0, \mathrm{q}$ \\
\hline $1-\mathrm{OH}$ & & & $12.50, \mathrm{~s}$ & \\
\hline $\begin{array}{l}6-\mathrm{OH} \\
7-\mathrm{OH}\end{array}$ & & & $3.76, d, 4.5$ & \\
\hline $8-\mathrm{OH}$ & $\begin{array}{l}4.12 \text {, br s } \\
4.72 \text {, br s }\end{array}$ & & & \\
\hline $10-\mathrm{OH}$ & 4.56 , br s & & $4.72, \mathrm{~d}, 8.0$ & \\
\hline
\end{tabular}

aAssignments made by DEPT, ${ }^{1} \mathrm{H}^{-1} \mathrm{H}$ COSY, HSQC, HMBC, and NOESY experiments. 
Coniothyrinone $\boldsymbol{C}$ ( $\boldsymbol{7}$ ). Colorless powder; m.p. $250-252^{\circ} \mathrm{C}$; $[\alpha] 20$ $\mathrm{D}=-2(c 0.12, \mathrm{MeOH}) ; \mathrm{CD}\left(\mathrm{CH}_{3} \mathrm{CN}, c=2.88 \times 10^{-4}\right): \lambda_{\max }(\varepsilon)=340 \mathrm{sh}$ (-2.15), 326 (-2.25), 263 (-7.01), 234sh (-1.49), 217 (14.72), 199 $(-1.78) \mathrm{nm}$; IR (film): $v_{\max }=3350,2919,2851,1633,1489,1064,897$, $781,744 \mathrm{~cm}^{-1}$; UV $(\mathrm{MeOH}): \lambda_{\max }(\log \varepsilon)=221$ (3.52), $234(2.97), 265$ (3.78), 284 (2.52), 330 (3.39) nm; ${ }^{1} \mathrm{H}$ NMR and ${ }^{13} \mathrm{C}$ NMR in [D] 6DMSO, see Table 2; HRESIMS: $m / z$ calcd for $\mathrm{C}_{15} \mathrm{H}_{17} \mathrm{O}_{5}: 277.1078$; found $277.1078[M-\mathrm{H}]^{+}$.

Coniothyrinone $\boldsymbol{D}(\boldsymbol{8})$. Colorless powder; m.p. $253-255^{\circ} \mathrm{C} ;[\alpha] 20$ $\mathrm{D}=-2(c 0.14, \mathrm{MeOH}) ; \mathrm{CD}\left(\mathrm{CH}_{3} \mathrm{CN}, c=3.60 \times 10^{-4}\right): \lambda_{\max }(\varepsilon)=360 \mathrm{sh}$ $(-1.98), 340$ (-5.55), 306 (7.48), 269 (1.24), 254sh (-0.37), 241 (-1.47), 230 (3.05), 213sh (-18.75), $204(-21.84) \mathrm{nm}$; IR (film): $v_{\max }=$ 3360, 2923, 2854, 1676, 1614, 1046, 860, $757 \mathrm{~cm}^{-1}$; UV (MeOH): $\lambda_{\max }$ $(\log \varepsilon)=226$ (3.90), 243 (3.66), 260 (3.85), 284 (3.22), 318 (3.46) nm;

${ }^{1} \mathrm{H}$ NMR and ${ }^{13} \mathrm{C}$ NMR in [D]6DMSO, see Table 2; HREIMS: $\mathrm{m} / z$ calcd for $\mathrm{C}_{15} \mathrm{H}_{18} \mathrm{O}_{5}: 278.1154$; found $278.1155[M]^{+}$.

\section{Agar Diffusion Test for Biological Activity}

Compounds 1-8 were dissolved in acetone at a concentration of $2 \mathrm{mg} /$ $\mathrm{ml} .25 \mu \mathrm{l}$ of the solution $(0.05 \mathrm{mg})$ were pipetted onto a sterile filter disc (Schleicher \& Schuell, $9 \mathrm{~mm}$ ), which was placed onto an appropriate agar growth medium for the respective test organisms and subsequently sprayed with a suspension of the test organisms. ${ }^{15}$ The test organisms were the Gram-negative bacterium E. coli, the Gram-positive bacterium $B$. megaterium (both grown on NB medium), the fungi $M$. violaceum, $B$. cinerea, and $S$. tritici, and the alga $C$. fusca (fungi and alga were grown on MPY medium). Reference substances were ketoconazole, penicillin, and streptomycin. Commencing at the outer edge of the filter disc, the radius of zone of inhibition was measured in $\mathrm{mm}$. These microorganisms were chosen because they are nonpathogenic and had in the past proved to be accurate initial test organisms for antibacterial, antifungal, and antialgal/herbicidal activities.

\section{Computational Section}

Mixed torsional/low mode conformational searches were carried out by means of the Macromodel 9.7.211 18 software using Merck Molecular Force Field (MMFF) with an implicit solvent model for chloroform and water. Geometry reoptimizations at B3LYP/6-31G(d) level of theory applying no or a PCM solvent model for AcN and DMSO followed by TDDFT calculations using various functionals (B3LYP, BH\&HLYP, CAM-B3LYP) and TZVP basis set were performed using the Gaussian $09^{19}$ package. Boltzmann distributions were estimated from the ZPVEcorrected B3LYP/6-31 G(d) energies of the optimized conformer geometries obtained at the same level of theory in the gas-phase calculations, and from the B3LYP/6-31 G(d) or the B3LYP/TZVP energies in the PCM calculations. ECD spectra were generated as the sum of Gaussians ${ }^{20}$ with 3000,2700 , and $2100 \mathrm{~cm}^{-1}$ half-height width (corresponding to ca. 12, 11, and $8 \mathrm{~nm}$ at $200 \mathrm{~nm}$ ), using dipole-velocity computed rotational strengths for conformers above $5 \%$. The MOLEKEL ${ }^{21}$ software package was used for visualization of the results.

\section{RESULTS AND DISCUSSION}

The fungus Coniothyrium sp. was cultivated on biomalt agar medium for 4 weeks, and then extracted with ethyl acetate. The crude extract was fractionated on silica gel, followed by Sephadex LH-20 column chromatography and reversed-phase HPLC to afford compounds 1-9.

On the basis of detailed spectroscopic analysis and by comparison with reported data, four known hydroxyanthraquinone analogues (1-4) were readily determined as 1-hydroxy-3methyl-9,10-anthraquinone (pachybasin, 1), 22,23 1,7-dihydroxy3-methyl-9,10-anthraquinone (2), ${ }^{24}$ 1,6-dihydroxy-3-methyl-9, 10-anthraquinone (phomarin, 3) ${ }^{24}$, and 1-hydroxy-3-hydroxymethyl-9,10-anthraquinone (4). ${ }^{25}$ The major metabolite pachybasin (1) was purified from the fungus Trichoderma harzianum ETS 323 with much higher yield ${ }^{23}$ and is mainly used as a yellow pigment. To the best of our knowledge, no biological activity of the four known analogues has yet been reported.

Coniothyrinone A (5) was isolated as a yellow powder, and its solution showed optical activity. The molecular formula $\mathrm{C}_{15} \mathrm{H}_{16} \mathrm{O}_{5}$ was established by HREIMS, indicating eight double bond equivalents. The IR spectrum showed absorption bands of a hydroxyl group $\left(3290 \mathrm{~cm}^{-1}\right)$, a carbonyl group $\left(1629 \mathrm{~cm}^{-1}\right)$, and a typical tetrasubstituted aromatic system (3027, 1567, $\left.1497,1452,849,767 \mathrm{~cm}^{-1}\right)$. This evidence was in agreement

TABLE 2. NMR data for coniothyrinones $C$ and $D(7,8)$ in [D]6DMSO

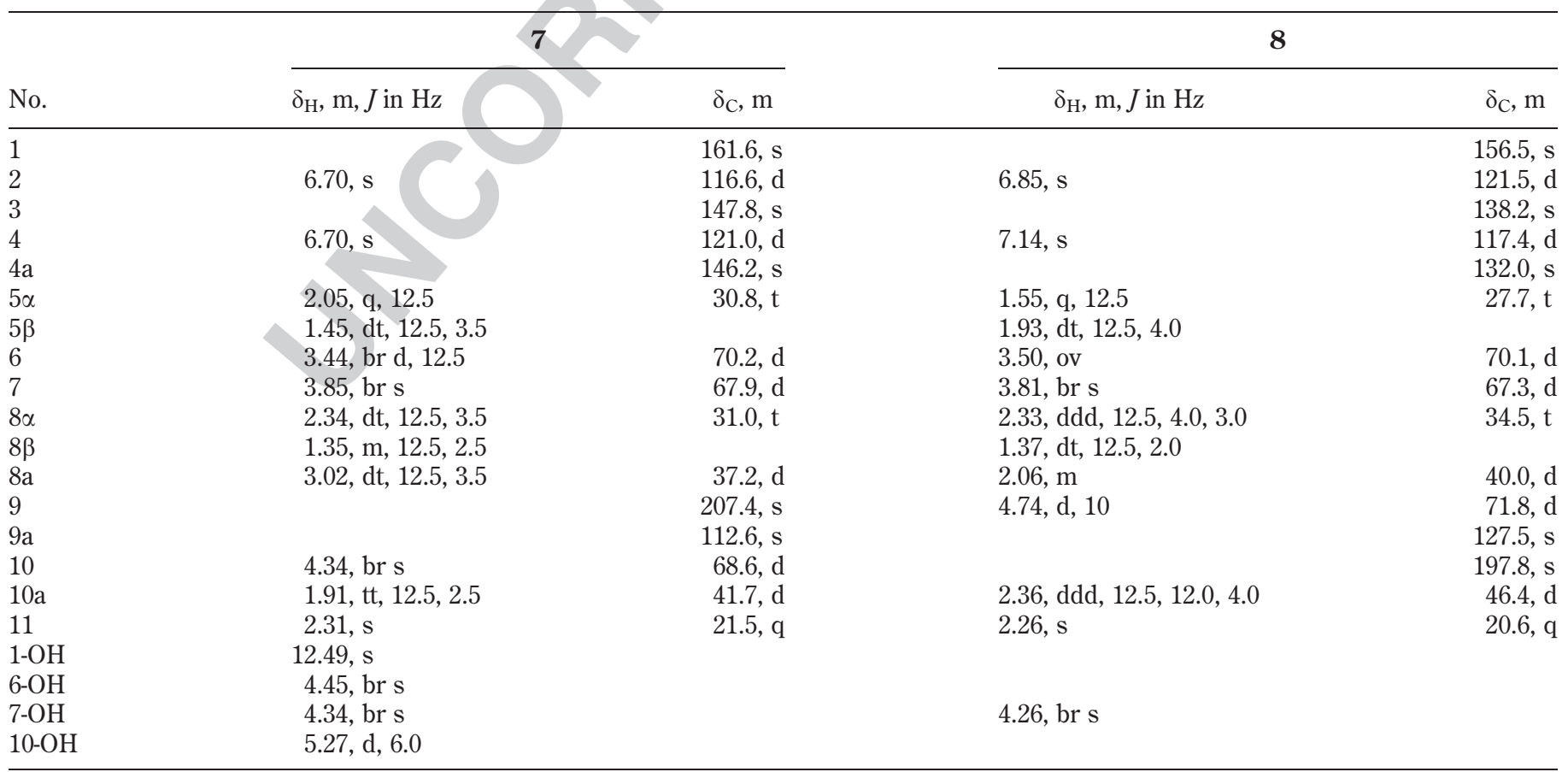

${ }^{\mathrm{a}}$ Assignments made by DEPT, ${ }^{1} \mathrm{H}-{ }^{1} \mathrm{H}$ COSY, HSQC, HMBC, and NOESY experiments 
with the observation of signals in the ${ }^{13} \mathrm{C}$ NMR and DEPT spectra for one carbonyl group $\left(\delta_{\mathrm{C}} 208.8\right)$, three secondary oxygenated carbons $\left(\delta_{\mathrm{C}} 69.26,73.65,74.47\right)$, six aromatic carbons $\left(\delta_{\mathrm{C}} 163.29,118.34,149.96,122.55,146.22,113.94\right)$, and one double bond $\left(\delta_{\mathrm{C}} 128.83,132.07\right)$ (Table 1$)$, accounting for six double bond equivalents. The remaining double bond equivalents were due to two additional rings in the molecule.

Comparison of the ${ }^{13} \mathrm{C}$ NMR spectrum of $\mathbf{5}$ with that of $\mathbf{1}$ immediately revealed similar signals related to ring $\mathrm{A}$, whereas the signals related to rings $\mathrm{B}$ and $\mathrm{C}$ were completely different. The presence of a chelated proton resonating at 11.89 and methyl protons at 2.34 in ${ }^{1} \mathrm{H}$ NMR spectrum supported the connection of ring A to the C-9 carbonyl. Analysis of the ${ }^{1} \mathrm{H}^{1}{ }^{1} \mathrm{H}$ COSY spectrum readily established the proton

F1 sequence of ring $\mathrm{C}$ and $\mathrm{H}-10$ (Fig. 1). Diagnostic HMBC correlations from $\mathrm{H}-10$ to $\mathrm{C}-4$ and $\mathrm{C}-8 \mathrm{a}$, and from $\mathrm{H}-8 \mathrm{a}$ to $\mathrm{C}-9$ and $\mathrm{C}-9 \mathrm{a}$, led to the connection of the two subunits to give the planar structure of $\mathbf{5}$.

The relative configuration of the chiral centers in rings $\mathrm{B}$ and $\mathrm{C}$ were suggested by a NOE experiment in combination with the analysis of the ${ }^{1} \mathrm{H}^{-1} \mathrm{H}$ coupling constant, aided by conformational analysis. As shown on the lowest-energy conformer (64.8\%) of $\mathbf{5}$, clear NOE effects between H-7 and $\mathrm{H}-8 \mathrm{a}$, and between $\mathrm{H}-8$ and $\mathrm{H}-10 \mathrm{a}$, indicated the 1,3-diaxial

F2 Q2 arrangement of the two pairs of protons (Fig. 2). The large coupling constants between $\mathrm{H}-8 \mathrm{a}$ and both $\mathrm{H}-8$ and $\mathrm{H}-10 \mathrm{a}$ $\left({ }^{3} J_{8,8 \mathrm{a}}=10.3 \mathrm{~Hz},{ }^{3} J_{8 \mathrm{a}, 10 \mathrm{a}}=9.2 \mathrm{~Hz}\right)$ further supported the above assignment, and consequently suggested the trans-annulation

Q3 of ring $\mathrm{B}$ and $\mathrm{C}$. The NOE effect with of $\mathrm{H}-10 \mathrm{H}-4$ as well as the small ${ }^{3} J$ values $(2.6 \mathrm{~Hz})$ between $\mathrm{H}-10$ and $\mathrm{H}-10$ a suggested the $\beta$ equatorial orientation of $\mathrm{H}-10$. Thus the $\left(7 S^{\star}, 8 S^{\star}, 8 \mathrm{a} R^{\star}\right.$, $\left.10 S^{\star}, 10 \mathrm{a} S^{\star}\right)$ relative configuration was determined.

The absolute configuration of coniothyrinone A (5) was determined by electronic circular dichroism (ECD) measurements aided by TDDFT ECD calculations. ${ }^{10-12,26}$ The ECD spectrum of $\mathbf{5}$ showed four main ECD bands: negative ones at 326,268 , and $229 \mathrm{~nm}$ and a positive one at $201 \mathrm{~nm}$. Lacking a reliable semiempirical ECD rule or ECD reference compound, the solution TDDFT ECD calculation protocol was used to

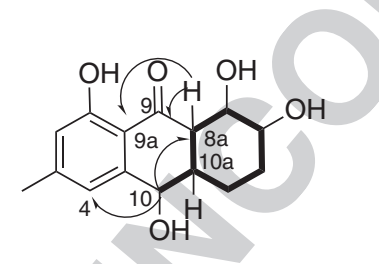

Fig. 1. ${ }^{1} \mathrm{H}^{-1} \mathrm{H}$ COSY (bold) and selected HMBC (arrow) correlations for 5.

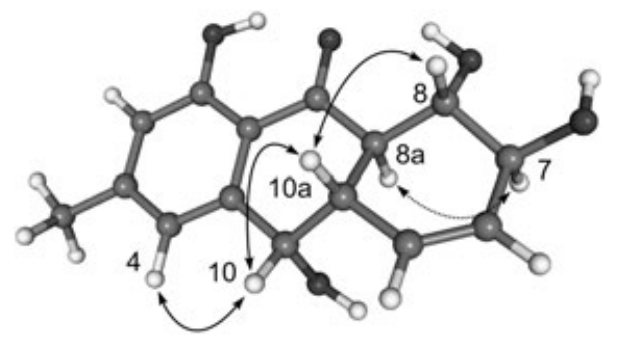

Fig. 2. Key NOESY correlations of $\mathbf{5}$ presented on the lowest-energy computed conformer $(64.8 \%)$. Interatomic distances in this conformer were found as $2.45 \AA$ for $\mathrm{H}-4-\mathrm{H}-10,2.43 \AA$ for $\mathrm{H}-10-\mathrm{H}-10 \mathrm{a}, 2.69 \AA$ for $\mathrm{H}-10 \mathrm{a}-\mathrm{H}-8$, and $2.51 \AA$ for $\mathrm{H}-8 \mathrm{a}-\mathrm{H}-7$.

Chirality DOI 10.1002/chir

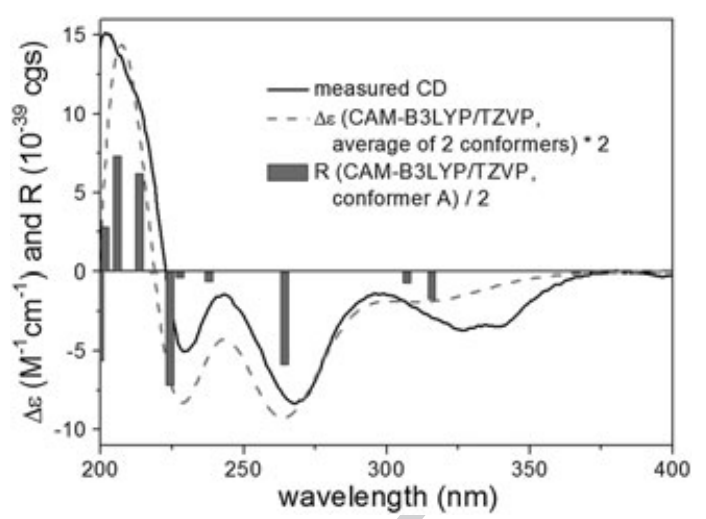

Fig. 3. Experimental ECD spectrum of $\mathbf{5}$ in acetonitrile compared with the CAM-B3LYP/TZVP Boltzmann-averaged spectrum calculated for the solution conformers of the $(7 S, 8 S, 8 \mathrm{a} R, 10 S, 10 \mathrm{a} S)$-enantiomer. Bars represent rotational strength values for the lowest-energy conformer.

determine the absolute configuration. The MMFF conformational search of coniothyrinone A (5) afforded three conformers in a $21 \mathrm{~kJ} / \mathrm{mol}$ range, the B3LYP/6-31 G(d) reoptimization of which resulted in two slightly different conformers $(64.8 \%$ and $34.8 \%$ ) above the $0.5 \%$ population (Fig. S1). The two conformers differed in the orientation for the proton of the axial 10-OH group; the fused carbocyclic ring of both had $M$ helicity with a positive $\omega_{4 a}, 10,10 a, 8 \mathrm{a}$ torsional angle $\left(24.3^{\circ}\right.$ for the lowest-energy conformer). The TDDFT ECD spectra of the $(7 S, 8 S, 8 \mathrm{a} R$, $10 S, 10 \mathrm{a} S$ )-enantiomer were calculated with the TZVP basis set and three functionals (B3LYP, BH\&HLYP, CAM-B3LYP) and all of them reproduced well the experimental ECD spectrum, with CAM-B3LYP giving the best agreement. Thus the absolute configuration of coniothyrinone A (5) was determined as (-)$(7 S, 8 S, 8 \mathrm{a} R, 10 S, 10 \mathrm{a} S)$. The characteristic long-wavelength band was determined by two overlapping ECD transitions at 316 and $307 \mathrm{~nm}$, from which the $316 \mathrm{~nm}$ one was a $\pi-\pi^{*}$ transition, while the $307 \mathrm{~nm}$ one was of $\mathrm{n}-\pi^{\star}$ type (CAM-B3LYP). The overlapping $\pi-\pi^{*}$ and $n-\pi^{*}$ transitions had the same sign contribution to the long-wavelength $\mathrm{CE}$, although the $\pi-\pi^{*}$ transition was more intense.

Coniothyrinone B (6) was isolated as a colorless powder; its solution showed optical activity. The molecular formula Q4 of $\mathrm{C}_{15} \mathrm{H}_{18} \mathrm{O}_{4}$, established by HRESIMS, indicated that it contains two more protons and one less oxygen compared to 5. The ${ }^{1} \mathrm{H}$ and ${ }^{13} \mathrm{C}$ NMR signals of 6 resembled those of $\mathbf{5}$ in rings $\mathrm{A}$ and $\mathrm{B}$, with the difference mainly resting in ring $\mathrm{C}$. The double bond and one of the secondary alcohols in ring $\mathrm{C}$ of $\mathbf{5}$ were replaced by two methylenes in $\mathbf{6}$ (Table 1). The remaining hydroxyl group was assigned to $\mathrm{C}-6$ due to the proton spin system of $\mathrm{H}-10 / \mathrm{H}-10 \mathrm{a} / \mathrm{H}_{2}-5 / \mathrm{H}-6 / \mathrm{H}_{2}-7 / \mathrm{H}_{2}-8 /$ $\mathrm{H}-8 \mathrm{a}$, deduced from the ${ }^{1} \mathrm{H}^{-1} \mathrm{H}$ COSY spectrum. The transannulation of rings $\mathrm{B}$ and $\mathrm{C}$ was established on the basis of the ${ }^{3} J$ value between $\mathrm{H}-8 \mathrm{a}$ and $\mathrm{H}-10 \mathrm{a}(11.8 \mathrm{~Hz})$. The $\beta$ orientation of H-6 was indicated by the obvious NOE effect between $\mathrm{H}-6$ and $\mathrm{H}-10 \mathrm{a}$, while the $\alpha$ arrangement of $\mathrm{H}-10$ was deduced from the NOE effect between H-10 and H-8a (Fig. 4), and Q5 from the ${ }^{3} J$ value $(11.8 \mathrm{~Hz})$ between $\mathrm{H}-10$ and $\mathrm{H}-10 \mathrm{a}$ (Table 1$)$, allowing the assignment of the relative configuration as $\left(6 S^{\star}, 8 \mathrm{a} S^{\star}, 10 R^{\star}, 10 \mathrm{a} S^{\star}\right)$.

Similar to coniothyrinones A (5), the ECD spectrum of coniothyrinone B (6) showed a negative CE for the 337-nm band, while the high-energy transitions at 267,234, and $216 \mathrm{~nm}$ had opposite CEs to the corresponding ones of coniothyrinone A (5). The DFT reoptimization of the six MMFF

1)

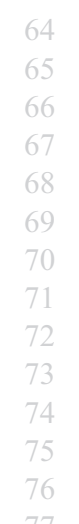




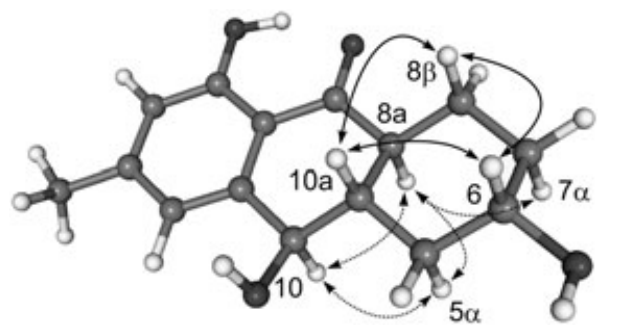

Fig. 4. Key NOESY correlations of coniothyrinone B (6) represented on the lowest-energy computed conformer. Interatomic distances in this conformer were found as $2.65 \mathrm{~A}$ for $\mathrm{H}-10 \mathrm{a}-\mathrm{H}-8 \beta, 2.61 \mathrm{~A}$ for $\mathrm{H}-10 \mathrm{a}-\mathrm{H}-6,2.63 \mathrm{~A}$ for $\mathrm{H}-8 \beta-\mathrm{H}-6,2.52 \AA$ for $\mathrm{H}-10-\mathrm{H}-8 \mathrm{a}, 2.52 \AA$ for $\mathrm{H}-10-\mathrm{H}-5 \alpha, 2.60 \AA$ for $\mathrm{H}-8 \mathrm{a}-\mathrm{H}-$ $5 \alpha$, and $2.63 \AA$ for $\mathrm{H}-8 \mathrm{a}-\mathrm{H}-7 \alpha$.

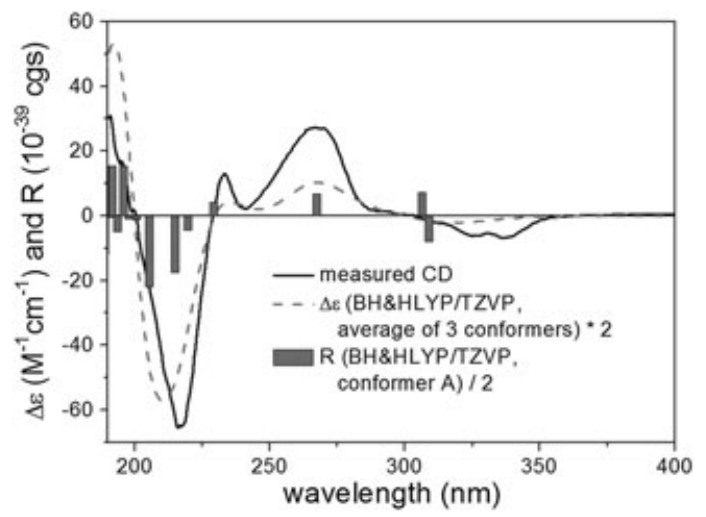

Fig. 5. Experimental ECD spectrum of 6 in acetonitrile compared with the BH\&HLYP/TZVP Boltzmann-averaged spectrum calculated for the solution conformers of the $(6 S, 8 \mathrm{a} S, 10 \mathrm{a} S, 10 R)$ - enantiomer. Bars represent rotational strength values for the lowest-energy conformer.

conformers of $(6 S, 8 \mathrm{a} S, 10 R, 10 \mathrm{a} S)-6$ resulted in three conformers above the $5 \%$ population, which differed only in the orientation of the 6-OH; their fused carbocyclic ring had $M$ helicity (Fig. S2). The TDDFT ECD spectra calculated for the three low-energy conformers $(6 S, 8 \mathrm{a} S, 10 R, 10 \mathrm{a} S)$-6 gave good agreement with the experimental curve, with the BH\&HLYP/TZVP showing the closest similarity (Fig. 11). Thus, the absolute configuration of coniothyrinone B (6) was assigned unambiguously as (-)-(6S,8aS,10R,10aS).

It is noteworthy that the C-8a annulation points of $\mathbf{5}$ and $\mathbf{6}$ are homochiral, although their CIP descriptors are different, which explains the same negative long-wavelength $\mathrm{CE}$ of $\mathbf{5}$ and $\mathbf{6}$. In contrast, the contiguous benzylic chirality center (C-10) has opposite absolute configuration in $\mathbf{5}$ and $\mathbf{6}$, which is responsible for the near-mirror image ECD curves below $300 \mathrm{~nm}$. On the basis of BH\&HLYP/TZVP calculation, the long-wavelength negative transition is governed by two oppositely signed transitions at 311 and $308 \mathrm{~nm}$, the former of which is a negative $\pi-\pi^{*}$ transition.

Coniothyrinone $\mathrm{C}$ (7) has a molecular formula of $\mathrm{C}_{15} \mathrm{H}_{18} \mathrm{O}_{5}$, as determined by HRESIMS; thus it possessed an additional oxygen atom compared to 6 . Comparison of the ${ }^{1} \mathrm{H}$ and ${ }^{13} \mathrm{C}$ NMR data of $\boldsymbol{7}$ with those of $\boldsymbol{6}$ revealed close similarity of rings $\mathrm{A}$ and $\mathrm{B}$, while ring $\mathrm{C}$ contained an additional secondary hydroxyl group at $\mathrm{C}-7$. The trans-annulation of rings $\mathrm{B}$ and $\mathrm{C}$ was indicated by the large ${ }^{3} \mathrm{~J}$ value between $\mathrm{H}-8 \mathrm{a}$ and $\mathrm{H}-10 \mathrm{a}$ $(12.5 \mathrm{~Hz})$. The NOE correlations of $\mathrm{H}-10 \mathrm{a}$ with $\mathrm{H}-6, \mathrm{H}-8 \beta$ and $\mathrm{H}-10$, and of $\mathrm{H}-6$ with $\mathrm{H}-7$ and $\mathrm{H}-8 \beta$, suggested the $\beta$ configuraF6 tion of these protons (Fig. 6). The small coupling constants observed between $\mathrm{H}-10$ and $\mathrm{H}-10 \mathrm{a}$, and between $\mathrm{H}-7$ and both

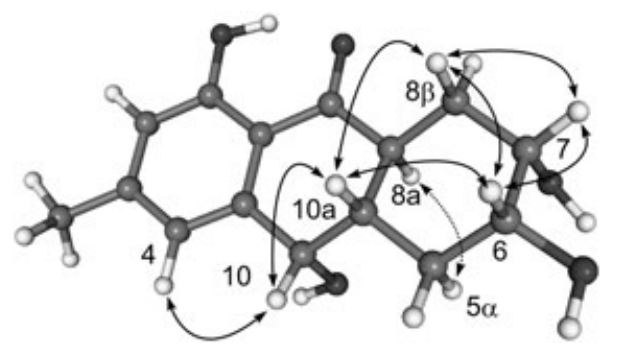

Fig. 6. Key NOESY correlations of coniothyrinone C (7) represented on the lowest-energy computed conformer. Interatomic distances in this conformer were found as $2.40 \AA$ for $\mathrm{H}-4-\mathrm{H}-10,2.43 \AA$ for $\mathrm{H}-10-\mathrm{H}-10 \mathrm{a}, 2.65 \AA$ for $\mathrm{H}-10 \mathrm{a}-$ $\mathrm{H}-8 \beta, 2.63 \AA$ for $\mathrm{H}-10 \mathrm{a}-\mathrm{H}-6,2.66 \AA$ for $\mathrm{H}-8 \beta-\mathrm{H}-6,2.43 \AA$ for $\mathrm{H}-8 \beta-\mathrm{H}-7,2.42 \AA$ for $\mathrm{H}-6-\mathrm{H}-7$, and $2.56 \AA$ for $\mathrm{H}-8 \mathrm{a}-\mathrm{H}-5 \alpha$.

H-6 and H-8 (Table 2) supported the above conclusion and afforded the $\left(6 R^{\star}, 7 S^{\star}, 8 \mathrm{a} S^{\star}, 10 S^{\star}, 10 \mathrm{a} S^{\star}\right)$ relative configuration.

Coniothyrinone $\mathrm{C}(\mathbf{7})$ showed negative $\mathrm{CEs}$ at 326,263 , and $234 \mathrm{~nm}$, and a positive one at $217 \mathrm{~nm}$; i.e., the same ECD pattern as coniothyrinone A (5). This suggested that $\mathbf{5}$ and $\mathbf{7}$ are homochiral at the chiral centers of C-8a, C-10a, and $\mathrm{C}-10$, which, on the basis of the known relative configuration, allowed determination of the absolute configuration of $\mathbf{7}$ as $(-)-(6 R, 7 S, 8 \mathrm{a} S, 10 S, 10 \mathrm{a} S)$.

Coniothyrinone D (8) was isolated as a colorless powder, and its solution showed optical activity. The molecular formula was established as $\mathrm{C}_{15} \mathrm{H}_{18} \mathrm{O}_{5}$ by HRESIMS. The ${ }^{1} \mathrm{H}^{1}{ }^{1} \mathrm{H}$ COSY spectrum gave a similar proton spin system to that of $\boldsymbol{7}$. However, this spin system was attached to C-9a instead of C-4a as suggested by the HMBC correlation from H-9 to C-9a. Moreover, the HMBC correlations from both $\mathrm{H}-4$ and $\mathrm{H}-10$ a to $\mathrm{C}-10$ assigned the ketone carbonyl group at C-10, and consequently settled the planar structure of the compound (Fig. 7). The lack F7 of the chelated hydroxyl proton signal in $\mathbf{8}$ corroborated well with the above conclusion. The NOE cross peaks between $\mathrm{H}-10 \mathrm{a}$ and $\mathrm{H}-6$, and $\mathrm{H}-8$ and $\mathrm{H}-9$, indicated the $\beta$ axial orientation of these protons (Fig. 8). The trans-diaxial arrangement $\mathbf{F 8}$ of H-8a and H-9 was deduced from their large proton coupling

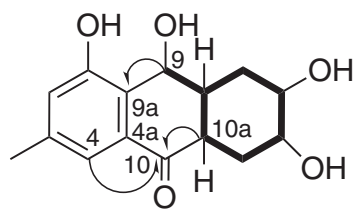

Fig. 7. ${ }^{1} \mathrm{H}^{-1} \mathrm{H}$ COSY (bond) and selected HMBC (arrow) correlations for 8.

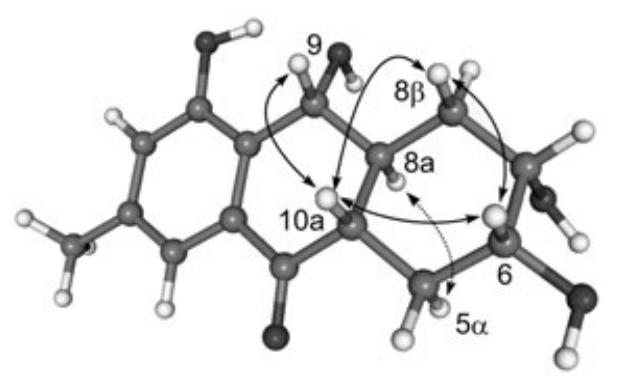

Fig. 8. Key NOESY correlations of coniothyrinone D (8) represented on the lowest-energy computed conformer. Interatomic distances in this conformer were found as $2.63 \AA$ for $\mathrm{H}-10 \mathrm{a}-\mathrm{H}-9,2.63 \AA$ for $\mathrm{H}-10 \mathrm{a}-\mathrm{H}-8 \beta, 2.65 \AA$ for $\mathrm{H}-10 \mathrm{a}-$ $\mathrm{H}-6,2.63 \AA$ for $\mathrm{H}-8 \beta-\mathrm{H}-6$, and $2.62 \AA$ for $\mathrm{H}-8 \mathrm{a}-\mathrm{H}-5 \alpha$. 
constant $\left({ }^{3} J_{8 \mathrm{a}, 9}=10 \mathrm{~Hz}\right)$, while the trans-annulation of rings $\mathrm{B}$ and $\mathrm{C}$ was further confirmed by the ${ }^{3} J$ value $(12.0 \mathrm{~Hz})$ of $\mathrm{H}-8 \mathrm{a}$ and H-10a. H-7 was assigned as an equatorial proton due to its NOE effect with both $\mathrm{H}-6$ and $\mathrm{H}-8 \alpha$. Thus, the relative configuration was determined as $\left(6 R^{\star}, 7 S^{\star}, 8 \mathrm{a} S^{\star}, 9 R^{\star}, 10 \mathrm{a} S^{\star}\right)$.

The ECD spectra of coniothyrinone D (8) was completely different from those of $\mathbf{5 - 7}$, which is attributed to the change of the relative position of the carbonyl group. Moreover, although the 1-OH was hydrogen bonded to the carbonyl oxygen in $\mathbf{5 - 7}$, this was not possible for $\mathbf{8}$, which was also reflected in the position of the long-wavelength ECD transitions. An intense negative $\mathrm{n}-\pi^{*} \mathrm{ECD}$ band appeared at $340 \mathrm{~nm}$ and a positive $\pi-\pi^{*}$ one at $306 \mathrm{~nm}$, i.e., the two longwavelength transitions were considerably separated, allowing the safe identification of the $\mathrm{n}-\pi^{*} \mathrm{CE}$. The DFT reoptimization of 13 MMFF conformers of $(6 R, 7 S, 8 \mathrm{a} S, 9 R, 10 \mathrm{a} S)-\mathbf{8}$ reduced the number of conformers to two (66.7\% and $22.8 \%)$ above the $5 \%$ population, which had both $M$ helicity and differed only in the orientation of the 6-OH (Fig. S3). The TDDFT ECD spectra were calculated for the two low-energy conformers with three functionals; the BH\&HLYP/TZVP

F9 method gave the best agreement (Fig. 9) allowing the determination of absolute configuration as (-)-(6R,7S,8aS,9R,10aS).

Coniothyrinones A-D (5-8) possess a fused tetralone [3,4-dihydronaphtelene-1 $(2 H)$-one] chromophore with various substitution patterns, quite a widespread phenomenon among natural products. ${ }^{29-37}$ Although there are $n-\pi^{*}$ helicity rules available correlating the helicity of the fused hetero-ring to the sign of the carbonyl $n-\pi^{\star}$ ECD transition in dihydroisocoumarines, ${ }^{38,39}$ flavanones ${ }^{40}$ 3-hydroxyflavanones, ${ }^{40}$ 2-alkylchromanones, ${ }^{41}$ and isoflavanones, ${ }^{42}$ similar correlation has not been found for tetralone derivatives, which can also be viewed as a cyclic aryl ketone. Moreover, some of the reported examples showed inconsistent relationship between the helicity of the fused nonaromatic ring and the sign of the long-wavelength $\mathrm{n}-\pi^{*}$ Cotton effect (CE) ${ }^{29-31,36}$ Since the tetralone chromophore is conformationally rigid in coniothyrinones A-D (5-8) due to the trans-annulation with ring $\mathrm{C}$ and has different substitution patterns, the ECD study of these derivatives can serve as a reference for the stereochemical studies of related derivatives. Although the fused ring B of 5-8 has $M$ helicity and the long-wavelength ECD transitions of the compounds had negative $\mathrm{CE}$, corroborating with the recent finding of Evidente et al., ${ }^{43}$ the ECD calculations revealed that the application of a universal $\mathrm{n}-\pi^{*}$ helicity rule is not feasible. In compounds 5-7, where the tetralone carbonyl oxygen was hydrogen bonded to the phenolic hydroxyl group, the ${ }^{1} \mathrm{~L}_{\mathrm{b}}$ and $n-\pi^{*}$ CEs overlap, making the use of the helicity rule ambiguous. In

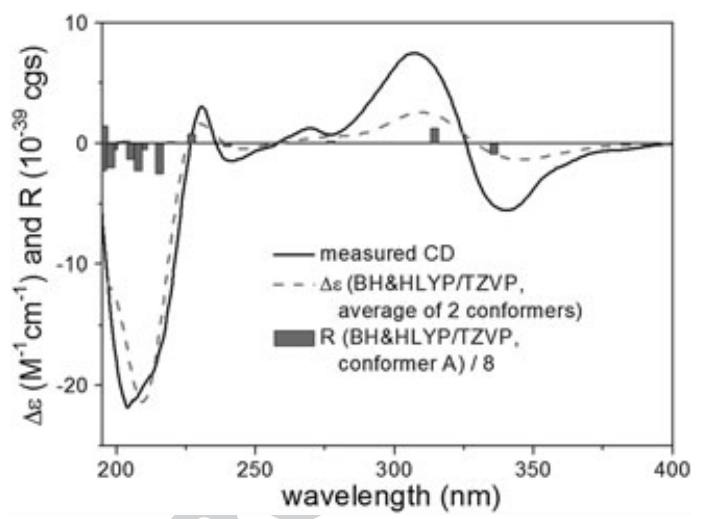

Fig. 9. Experimental ECD spectrum of 8 in acetonitrile compared with the BH\&HLYP/TZVP Boltzmann-averaged spectrum calculated for the solution conformers of the $(6 R, 7 S, 8 \mathrm{a} S, 9 R, 10 \mathrm{a} S)$ - enantiomer. Bars represent rotational strength values for the lowest-energy conformers.

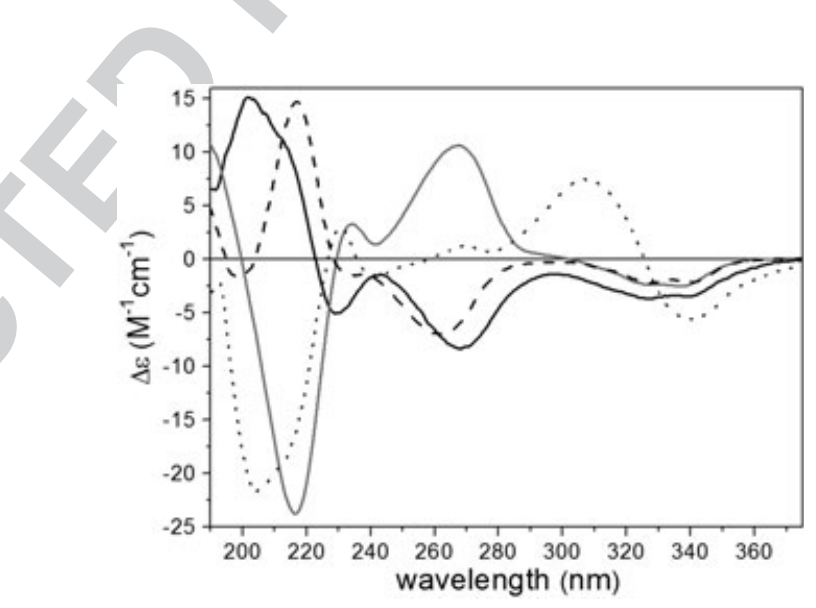

Fig. 10. Solution ECD spectra of coniothyrinones A-D (5-8) in acetonitrile; coniothyrinone A (5, black curve), coniothyrinone B (6, grey curve), coniothyrinone C ( $\mathbf{7}$, dashed curve), coniothyrinone D (8, dotted curve).

TABLE 3. Agar diffusion assays for antibacterial, antifungal, and antialgal activities ${ }^{\mathrm{a}}$

\begin{tabular}{|c|c|c|c|c|c|c|}
\hline \multirow[b]{2}{*}{ No. } & \multicolumn{3}{|c|}{ Fungi } & \multicolumn{2}{|c|}{ Bacteria } & \multirow{2}{*}{$\begin{array}{c}\text { Alga } \\
\text { C. fusca }\end{array}$} \\
\hline & M. violaceum & B. inerea & S. tritici & E. coli & B. megaterium & \\
\hline$\overline{\mathbf{1}}$ & 0 & 0 & 0 & 0 & 7 & 0 \\
\hline 3 & 10 & 9 & 7 & 11 & 11 & 0 \\
\hline 4 & 8 & 9 & 7.5 & 15 & 16 & 0 \\
\hline 5 & 7.5 & 12.5 & 6 & 7.5 & 8 & 0 \\
\hline 8 & 7.5 & 0 & 5 & 6 & 10 & 0 \\
\hline Penicillin & 6 & 0 & 8 & 10 & 26 & 0 \\
\hline Streptomycin & 7.5 & 0 & 6 & 0 & 13 & 0 \\
\hline Ketoconazole & 11 & 9 & 13 & 0 & 0 & 0 \\
\hline Acetone & 0 & 0 & 0 & 0 & 0 & 0 \\
\hline
\end{tabular}

${ }^{\mathrm{a}} 50 \mu \mathrm{g}$ of the test or control substances dissolved in acetone were applied to a filter disc and sprayed with the respective test organism. Radii of the zones of inhibition are given in $\mathrm{mm}$.

Chirality DOI 10.1002/chir 
<smiles>[R]c1cc(O)c2c(c1)C(=O)c1cc([R])c([R])c([R4])c1C2=O</smiles>

$1 \mathrm{R}_{1}=\mathrm{CH}_{3}, \mathrm{R}_{2}=\mathrm{R}_{3}=\mathrm{R}_{4}=\mathrm{H}$

$2 \mathrm{R}_{1}=\mathrm{CH}_{3}, \mathrm{R}_{2}=\mathrm{R}_{4}=\mathrm{H}, \mathrm{R}_{3}=\mathrm{OH}$

$3 \mathrm{R}_{1}=\mathrm{CH}_{3}, \mathrm{R}_{2}=\mathrm{OH}, \mathrm{R}_{3}=\mathrm{R}_{4}=\mathrm{H}$

$4 \mathrm{R}_{1}=\mathrm{CH}_{2} \mathrm{OH}, \mathrm{R}_{2}=\mathrm{R}_{3}=\mathrm{R}_{4}=\mathrm{H}$

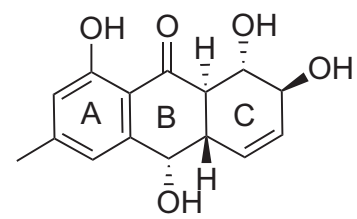

5

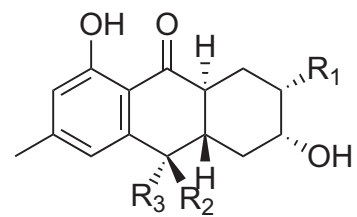

$6 \mathrm{R}_{1}=\mathrm{R}_{3}=\mathrm{H}, \mathrm{R}_{2}=\mathrm{OH}$

$7 \mathrm{R}_{1}=\mathrm{R}_{3}=\mathrm{OH}, \mathrm{R}_{2}=\mathrm{H}$<smiles>Cc1cc(O)c2c(c1)C(=O)[C@@H]1C[C@@H](O)[C@H](O)C[C@H]1[C@H]2O</smiles>

8
Chart 1. Structures 1-8 isolated from Coniothyrium sp.

contrast, the long-wavelength ECD transition of $\mathbf{8}$, where the carbonyl oxygen has no possibility for intramolecular hydrogen bonding, is of pure $n-\pi^{\star}$ origin. In conclusion, ECD calculations are strongly recommended for the configurational assignment of tetralone derivatives whenever close analogues are not avail-

F10 able for ECD reference (Fig. 10).

Compounds 1-8 were tested in an agar diffusion assay for their antifungal, antibacterial, and algicidal properties toward Microbotryum violaceum, Botrytis cinerea, Septoria tritici, Escherichia coli, Bacillus megaterium, and Chlorella T3 fusca (Table 3). Compounds 2-8 displayed antimicrobial activity in the test. In particular, compound $\mathbf{4}$ displayed potent antibacterial activity against both the Gram-positive bacterium $B$. megaterium and the Gram-negative bacterium E. coli. Compounds $\mathbf{3}$ and $\mathbf{5}$ showed strong antifungal activity against $M$. violaceum and $B$. cinerea. The major metabolite pachybasin (1) was only weakly active against the Gram-positive bacterium Q6 B. megaterium. Chart 1

\section{CONCLUSIONS}

The discovery of an array of hydroxyanthraquinone derivatives demonstrates the productivity of the fungus and represents an example of chemical diversity. Apparently, the cluster of the new metabolites, coniothyrinones A-D (5-8), may biogenetically derive from the common hydroxyanthraquinones 1-4 by reduction on one of the keto groups in ring $\mathrm{B}$ and hydrogenation and/or $\mathrm{H}_{2} \mathrm{O}$ addition on the double bond of ring $\mathrm{C}$, whereas ring $\mathrm{A}$ of these molecules remains intact. Stereochemical study of the isolated derivatives including conformational analysis and TDDFT ECD calculation revealed the origin of subtle differences in their solution ECD spectra and allowed the correlation of the stereochemistry to the characteristic ECD transitions.

\section{ACKNOWLEDGEMENTS}

Contract grant sponsor: Natural Science Foundation of China; Contract grant number: 41076082, 81172979.

Contract grant sponsor: the Shanghai Pujiang Program; Contract grant number: PJ2008.

Contract grant sponsor: the HURO/0901/274/2.2.2 project (websites: www.huro-cbc.eu and www.hungary-romania-cbc.eu).

\section{LITERATURE CITED}

1. Schulz B, Draeger S, dela Cruz TE, Rheinheimer J, Siems K, Loesgen S, Schloerke J, Zeeck A, Kock I, Hussein H, Dai J, Krohn K. Screening strategies for obtaining novel, biologically active, fungal secondary metabolites from marine habitats. Botanica Marina 2008;51:219-234.

2. Krohn K, Michel A, Flörke U, Aust H-J, Draeger S, Schulz B. Palmarumycins C1-C16 from Coniothyrium sp.: isolation, structure elucidation, and biological activity. Liebigs Ann Chem 1994;1099-1108.

3. Kock I, Krohn K, Egold H, Draeger S, Schulz B, Rheinheimer J. New massarilactones, massarigenin E, and coniothyrenol, isolated from the endophytic fungus Coniothyrium sp. from Carpobrotus edulis. Eur J Org Chem 2007;2186-2190.

4. Krohn K, Zia-Ullah, Hussain H, Flörke U, Schulz B, Draeger S, Pescitelli G, Salvadori P, Antus S, Kurtán T. Massarilactones E-G, new metabolites from the endophytic fungus Coniothyrium sp., associated with the plant Artimisia maritime. Chirality 2007;19: 464-470.

5. Krohn K, Kouam S, Cludius-Brandt S, Draeger S, Schulz B. Bioactive nitronaphthalenes from an endophytic fungus, Coniothyrium sp., and their chemical synthesis. Eur J Org Chem 2008;3615-3618.

6. Krohn K, Michel A, Flörke U, Aust H-J, Draeger S, Schulz B. Palmarumycins CP1-CP4 from Coniothyrium palmarum: isolation, structure elucidation, and biological activity. Liebigs Ann Chem 1994;1093-1097.

7. Krohn K, Beckmann K, Flörke U, Aust H-J, Draeger S, Schulz B, Busemann S, Bringmann G. New palmarumycins cp4a and cp 5 from Coniothyrium palmarum: structure elucidation, crystal structure analysis and determination of the absolute configuration by $\mathrm{CD}$ calculations. Tetrahedron 1997;53:3101-3110.

8. Machida K, Trifonov LS, Ayer WA, Lu Z-X, Laroche A, Huang HC, Cheng $\mathrm{KJ}$, Zantinge JL. $3(2 \mathrm{H})$-Benzofuranones and chromanes from liquid cultures of the mycoparasitic fungus Coniothyrium minitans. Phytochemistry 2001;58:173-177.

9. Höller $\mathrm{U}$, König GM, Wright $\mathrm{AD}$. Three new metabolites from marinederived fungi of the genera Coniothyrium and Microsphaeropsis. J Nat Prod 1999;62:114-118.

10. Lu S, Sun P, Li T, Kurtán T, Mándi A, Antus S, Krohn K, Draeger S, Schulz B, Yi Y, Li L, Zhang W. Bioactive nonanolide derivatives isolated from the endophytic fungus Cytospora sp. J Org Chem 2011;76:9699-9710.

11. Lu S, Kurtán T,'YYang G, Sun P, Mándi A, Krohn K, Draeger S, Schulz B, Yi Y, Li L, Zhang W. Cytospolides A-E, novel nonanolides from an endophytic fungus, Cytospora sp. Eur J Org Chem 2011;1:5452-5459.

12. Zhang W, Krohn K, Zia-Ullah, Flörke U, Pescitelli G, Bari LD, Antus S, Kurtán T, Rheinheimer J, Draeger S, Schulz B. New mono- and dimeric members of the secalonic acid family, blennolides A-G, isolated from the fungus Blennoria sp. Chem Eur J 2008;14:4913-4923.

13. Zhang W, Krohn K, Egold H, Draeger S, Schulz B. Diversity of antimicrobial macrodiolide derivatives from an endophytic fungus, Phoma sp. Eur J Org Chem 2008;4320-4328.

14. Zhang W, Krohn K, Draeger S, Schulz B. Bioactive isocoumarins isolated from endophytic fungus Microdochium bolleyi. J Nat Prod 2008;71:1078-1081.

15. Schulz B, Sucker J, Aust HJ, Krohn K, Ludewig K, Jones PG, Döring D. Biologically active secondary metabolites of endophytic Pezicula species. Mycol Res 1995;99:1007-1015.

16. Höller U, Wright AD, Matthée GF, Konig GM, Draeger S, Aust HJ, Schulz B. Fungi from marine sponges: diversity, biological activity and secondary metabolites. Mycol Res 2000;104:1354-1365.

17. Krohn K, Flörke U, Rao MS, Steingröver K, Aust HJ, Draeger S, Schulz B. Metabolites from Fungi 15. New Isocoumarins from an endophytic fungus isolated from the Canadian thistle Cirsium arvense. Nat Prod Lett 2001;15:353-361.

18. MacroModel. Schrödinger LLC, 2009. http://www.schrodinger.com/ Products/macromodel.html.

19. Frisch MJ, Trucks GW, Schlegel HB, Scuseria GE, Robb MA, Cheeseman JR, Scalmani G, Barone V, Mennucci B, Petersson GA, Nakatsuji H, Caricato M, Li X, Hratchian HP, Izmaylov AF, Bloino J, Zheng G, Sonnenberg JL, Hada M, Ehara M, Toyota K, Fukuda R, Hasegawa J, Ishida M, Nakajima T, Honda Y, Kitao O, Nakai H, Vreven T, Montgomery JA, Peralta JE Jr, Ogliaro F, Bearpark M, Heyd JJ, Brothers E, Kudin KN, Staroverov VN, Kobayashi R, Normand J, Raghavachari K, Rendell A, Burant JC, Iyengar SS, Tomasi J, Cossi M, Rega N, Millam JM, Klene M, Knox JE, Cross JB, Bakken V, Adamo C, Jaramillo J, Gomperts R, Stratmann RE, Yazyev O, Austin AJ, Cammi R, Pomelli C, Ochterski JW, Martin RL, Morokuma K, Zakrzewski VG, Voth GA, Salvador P, Dannenberg JJ, Dapprich S, Daniels 
AD, Farkas O, Foresman JB, Ortiz JV, Cioslowski J, Fox DJ. Gaussian 09, Revision B.01. Wallingford, CT: Gaussian, Inc; 2010.

20. Stephens PJ, Harada N. ECD Cotton effect approximated by the Gaussian curve and other methods. Chirality 2010;22:229-233.

21. Varetto U. MOLEKEL 5.4. Manno, Switzerland: Swiss National SupercomQ18 puting Centre; 2009.

22. Slater GP, Haskins RH, Hogge LR, Nesbitt LR. Metabolic products from a Trichoderma viride Pers. ex Fries. Can J Chem 1967;45:92-96.

23. Liu S-Y, Lo C-T, Chen C, Liu M-Y, Chen J-H, Peng K-C. Efficient isolation of anthraquinone-derivatives from Trichoderma harzianum ETS 323. J Biochem Biophys Meth 2007;70:391-395.

24. Borges WS, Pupo MT. Novel anthraquinone derivatives produced by Phoma sorghina, an endophyte found in association with the medicinal plant Tithonia diversifolia (Asteraceae). J Braz Chem Soc 2006;17:929-934.

25. Erturk S, Imre S. Anthraquinones from the roots of Digitalis grandiflora. Acta Pharm Turcica 2001;43:73-75.

26. Li C, La M-P, Sun P, Kurtán T, Mándi A, Tang H, Liu B-S, Yi Y, Li L, Zhang W. Bioactive $(3 Z, 5 E)$-11,20-epoxybriara-3,5-diene-7,18-olide diterpenoids from the South China Sea gorgonian Dichotella gemmacea. Mar Drugs 2011;9:1403-1418.

Q19 27. Cai Y-S, Kurtán T, Miao Z-H, Mándi A, Komáromi I, Liu H-L, Ding J, Guo Y-W. Palmarumycins BG1-BG7 and preussomerin BG1: establishment of their absolute configurations using theoretical calculations of electronic circular dichroism spectra. J Org Chem 2011;76:1821-1830.

Q20 28. Nicu VP, Neugebauer J, Baerends EJ. Effects of complex formation on vibrational circular dichroism spectra. J Phys Chem A 2008;112:6978-6991.

29. Chen, YL, Tan CH, Tan JJ, Qu SJ, Jiang SH, Zhu DY. Two new isomeric a-tetralones from Pyrola calliantha. Planta Med 2008;74:1826-1828.

30. Allouche N, Morleo B, Thoison O, Dumontet V, Nosjean O, Gueritte F, Sevenet T, Litaudon M. Biologically active tetralones from New Caledonian Zygogynum spp. Phytochemistry 2008;69:1750-1755.

31. Liu L, Li A-L, Zhao M-B, Tu P-F. Tetralones and flavonoids from Pyrola calliantha. Chem Biodivers 2007;4:2932-2937.

32. Machida K, Matsuoka E, Kasahara T, Kikuchi M. Studies on the constituents of Juglans species. I. Structural determination of $(4 S)$ - and $(4 R)$ 4-hydroxy- $\alpha$-tetralone derivatives from the fruit of Juglans mandshurica Maxim. var. sieboldiana Makino. Chem Pharm Bull 2005;53:934-937.
33. Couche E, Fkyerat A, Tabacchi R. Asymmetric synthesis of the cis- and trans-3,4-dihydro-2,4,8-trihydroxynaphthalen-1 $(2 H)$-ones. Helv Chim Acta 2003;86:210-221.

34. Laurent D, Guella G, Mancini I, Roquebert MF, Farinole F, Pietra F. A new cytotoxic tetralone derivative from Humicola grisea, a filamentous fungus from wood in the southeastern lagoon of New Caledonia. Tetrahedron 2002;58:9163-9167.

35. Bringmann G, Messer K, Saeb W, Petes EM, Peters K. The absolute configuration of (+)-isoshinanolone and in situ LC-CD analysis of its stereoisomers from crude extracts. Phytochemistry 2001;56:387-391.

36. Kagawa K, Tokura K, Uchida K, Kakushi H, Shike T, Nakai H. Platelet aggregation inhibitors and inotropic constituents in Pyrolae herba. Chem Pharm Bull 1992;40:2083-2087.

37. Thiem J, Gerken M, Snatzke G. Synthese des tetradesoxydisaccharids D-C der aureolsäuren. Liebigs Ann Chem 1983;448-461.

38. Hussain H, Akhtar N, Draeger S, Schulz B, Pescitelli G, Salvadori P, Antus S, Kurtán T, Krohn K. New bioactive 2,3-epoxycyclohexenes and isocoumarins from the endophytic fungus Phomopsis sp. from Laurus azorica. Eur J Org Chem 2009;749-756.

39. Krohn K, Kock I, Elsasser B, Flörke U, Schulz B, Draeger S, Pescitelli G, Antus S, Kurtán T. Bioactive natural products from the endophytic fungus Ascochyta sp. from Meliotus dentatus-configurational assignment by solid-state CD and TDDFT calculations. Eur J Org Chem 2007;1123-1129.

40. Gaffield W. Circular dichroism, optical rotatory dispersion and absolute configuration of flavanones, 3-hydroxyflavanones and their glycosides: determination of aglycone chirality in flavanone glycosides. Tetrahedron 1970;26:4093-4108.

41. McGahren WJ, Ellestad GA, Morton GO, Kunstman MP. LL-D253 $\alpha,-\beta$, and $-\gamma$, novel chromanones from the fungus Phoma pigmentivora. J Org Chem 1972;37:1636-1639.

42. Galeffi C, Rasoanaivo P, Federici E, Palazzino G, Nicoletti M, Rasolondratovo B. Two prenylated isoflavanones from Millettia pervilleana. Phytochemistry 1997;45:189-192.

43. Evidente A, Superchi S, Cimmino A, Mazzeo G, Mugnai L, Rubiales D, Andolfi A, Villegas-Fernández AM. Regiolone and isosclerone, two enantiomeric phytotoxic naphthalenone pentaketides: computational assignment of absolute configuration and its relationship with phytotoxic activity. Eur J Org Chem 2011;5564-5570. 


\section{Author Query Form}

\section{Journal: Chirality}

\section{Article: chir_22128}

Dear Author,

During the copyediting of your paper, the following queries arose. Please respond to these by annotating your proofs with the necessary changes/additions.

- If you intend to annotate your proof electronically, please refer to the E-annotation guidelines.

- If you intend to annotate your proof by means of hard-copy mark-up, please refer to the proof mark-up symbols guidelines. If manually writing corrections on your proof and returning it by fax, do not write too close to the edge of the paper. Please remember that illegible mark-ups may delay publication.

Whether you opt for hard-copy or electronic annotation of your proofs, we recommend that you provide additional clarification of answers to queries by entering your answers on the query sheet, in addition to the text mark-up.

\begin{tabular}{|c|c|c|}
\hline Query No. & Query & Remark \\
\hline Q1 & $\begin{array}{l}\text { AUTHOR: Please supply a substantially shortened version of the article title to be used as a } \\
\text { running head for your article. }\end{array}$ & \\
\hline Q2 & $\begin{array}{l}\text { AUTHOR: Figure } 3 \text { was not cited in the text. An attempt has been made to insert the figure } \\
\text { into a relevant point in the text - please check that this is OK. If not, please provide clear } \\
\text { guidance on where it should be cited in the text. }\end{array}$ & \\
\hline Q4 & $\begin{array}{l}\text { AUTHOR: P. } 9 \text { of mss PDF, lines 49-50: "The molecular formula of } \mathrm{C}_{15} \mathrm{H}_{18} \mathrm{O}_{4} \text {, established by } \\
\text { HRESIMS, indicated that it contains two more protons and one less oxygen compared to 5." }\end{array}$ & \\
\hline Q6 & $\begin{array}{l}\text { AUTHOR: Chart } 1 \text { was not cited in the text. An attempt has been made to insert the figure } \\
\text { into a relevant point in the text - please check that this is OK. If not, please provide clear } \\
\text { guidance on where it should be cited in the text. }\end{array}$ & \\
\hline Q7 & AUTHOR: Please check capturing of Acknowledgement if correct. & \\
\hline Q8 & $\begin{array}{l}\text { AUTHOR: References } 27 \text { and } 28 \text { do not appear to be called out in text. Please add callouts } \\
\text { or delete the references and renumber the remainder. }\end{array}$ & \\
\hline Q9 & $\begin{array}{l}\text { AUTHOR: Please note that there is no text callout for Figure } 3 \text { or Figure } 5 \text {. Please provide. } \\
\text { Note also that there is a callout for Figure 11, approximately where Figure } 5 \text { should be - and } \\
\text { there is no Figure } 11 .\end{array}$ & \\
\hline Q13 & AUTHOR: Please provide initials for Zia-Ullah, for reference 4. & \\
\hline
\end{tabular}




\begin{tabular}{|c|c|c|}
\hline Query No. & Query & Remark \\
\hline Q14 & AUTHOR: Please provide volume. & \\
\hline Q15 & AUTHOR: Please provide volume. & \\
\hline Q16 & AUTHOR: Please provide initials for Zia-Ullah, for reference 12. & \\
\hline Q17 & AUTHOR: Please provide volume. & \\
\hline Q18 & AUTHOR: Please check this presentation if correct. & \\
\hline Q19 & $\begin{array}{l}\text { AUTHOR: Reference " } 27 \text { " has not cited in the text. Please indicate where it should be cited; } \\
\text { or delete from the reference list and renumber the references in the text and reference list. }\end{array}$ & \\
\hline Q20 & $\begin{array}{l}\text { AUTHOR: Reference " } 28 \text { " has not cited in the text. Please indicate where it should be cited; } \\
\text { or delete from the reference list and renumber the references in the text and reference list. }\end{array}$ & \\
\hline Q21 & AUTHOR: Please provide volume. & \\
\hline Q22 & AUTHOR: Please provide volume. & \\
\hline Q23 & AUTHOR: Please provide volume. & \\
\hline Q24 & AUTHOR: Please provide volume. & \\
\hline
\end{tabular}


Required software to e-Annotate PDFs: Adobe Acrobat Professional or Adobe Reader (version 7.0 or above). (Note that this document uses screenshots from Adobe Reader $\mathrm{X}$ )

The latest version of Acrobat Reader can be downloaded for free at: http://get.adobe.com/uk/reader/

Once you have Acrobat Reader open on your computer, click on the Comment tab at the right of the toolbar:

닙

This will open up a panel down the right side of the document. The majority of tools you will use for annotating your proof will be in the Annotations section, pictured opposite. We've picked out some of these tools below:

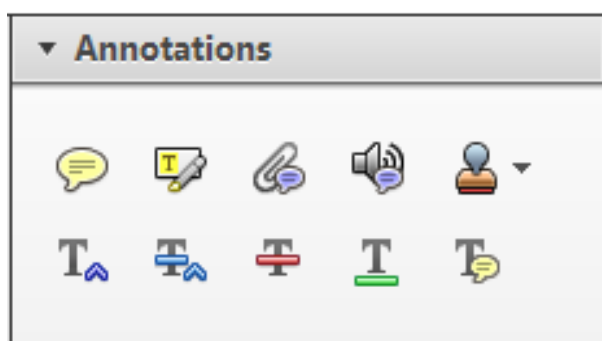

1. Replace (Ins) Tool - for replacing text.

Strikes a line through text and opens up a text box where replacement text can be entered.

How to use it

- Highlight a word or sentence.

- Click on the Replace (Ins) icon in the Annotations section.

- Type the replacement text into the blue box that appears.

Idard tramework for the analysis of $\mathrm{m}$ icy-Nevertheless, it also led to exog،

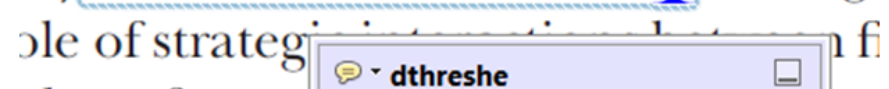
\begin{tabular}{l|l|l} 
aber of comp & 08/06/2011 15:58:17 & 0
\end{tabular} is that the $\mathrm{s} 1 \overline{\text {, which led }}$ of nain compo: be level, are exc nc

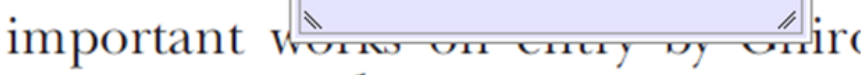
M heneferth) ${ }^{1}$ we anen the "hlarl $\mathrm{h}$

3. Add note to text Tool - for highlighting a section to be changed to bold or italic.

T Highlights text in yellow and opens up a text box where comments can be entered.

How to use it

- Highlight the relevant section of text.

- Click on the Add note to text icon in the Annotations section.

- Type instruction on what should be changed regarding the text into the yellow box that appears.

namic responses of mark ups ent with the VAR evidence

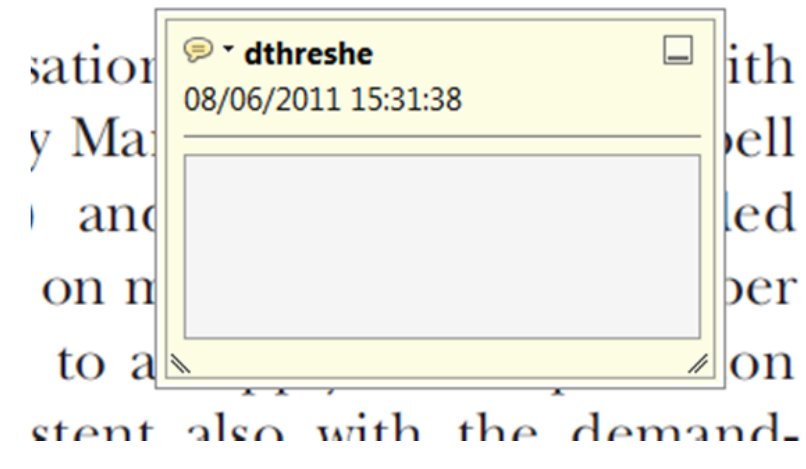

2. Strikethrough (Del) Tool - for deleting text.

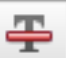

Strikes a red line through text that is to be deleted.

How to use it

- Highlight a word or sentence.

- Click on the Strikethrough (Del) icon in the Annotations section.

there is no room tor extra prohts al s ups are zero and the number of ret) values are not determined by Blanchard and Kiyotaki (1987), sfect competition in general equilil ts of aggregate demand and supply lassical framework assuming monol sen an evorenous number of firms

4. Add sticky note Tool - for making notes at specific points in the text.

Marks a point in the proof where a comment needs to be highlighted.

How to use it

- Click on the Add sticky note icon in the Annotations section.

- Click at the point in the proof where the comment should be inserted.

- Type the comment into the yellow box that appears.

iaisu airu suppiy sisuks. hivsl ui

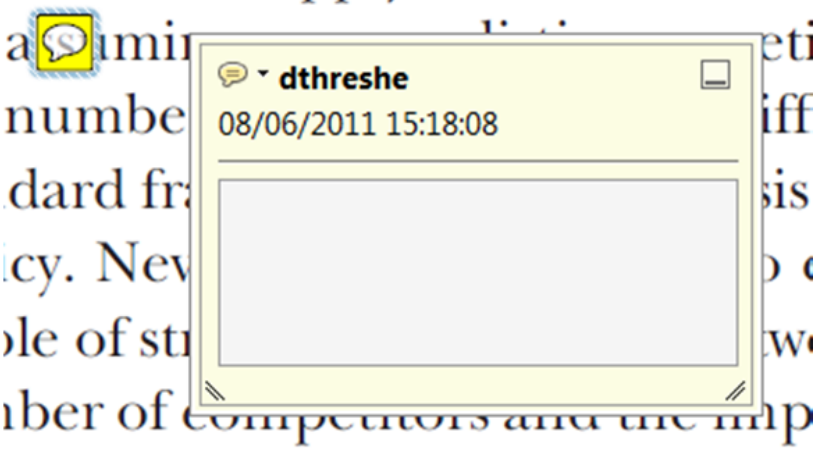

is that the structure of the sectc. 
5. Attach File Tool - for inserting large amounts of text or replacement figures.

Inserts an icon linking to the attached file in the appropriate pace in the text.

How to use it

- $\quad$ Click on the Attach File icon in the Annotations section.

- Click on the proof to where you'd like the attached file to be linked.

- Select the file to be attached from your computer or network.

- Select the colour and type of icon that will appear in the proof. Click OK.

E N D

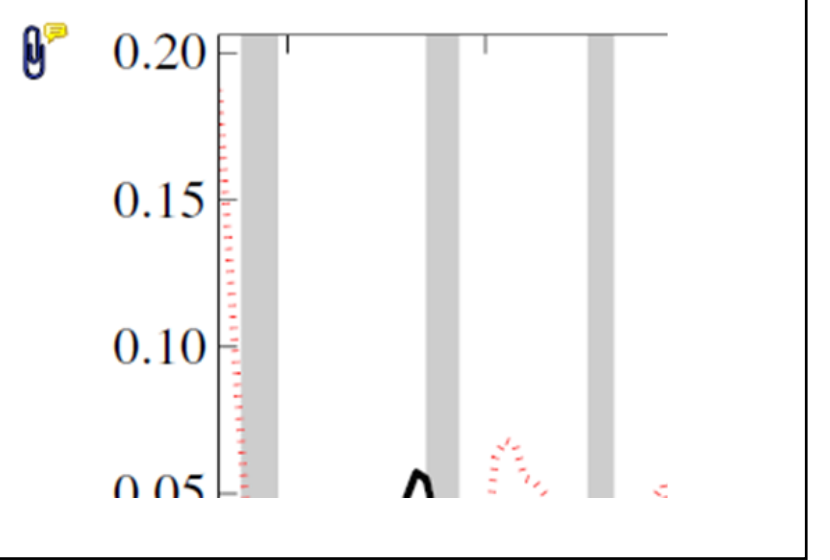

6. Add stamp Tool - for approving a proof if no corrections are required.

- Inserts a selected stamp onto an appropriate place in the proof.

\section{How to use it}

- $\quad$ Click on the Add stamp icon in the Annotations section.

- Select the stamp you want to use. (The Approved stamp is usually available directly in the menu that appears).

- Click on the proof where you'd like the stamp to appear. (Where a proof is to be approved as it is, this would normally be on the first page).

)t the Dusiness cycie, starting with the on perfect competition, constant ret

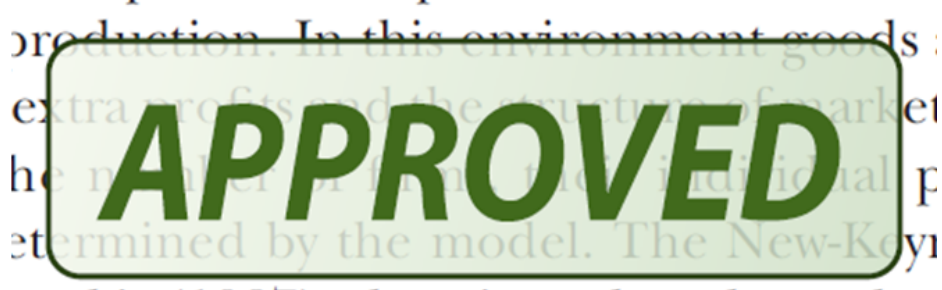
otaki (1987), has introduced produc general equilibrium models with nomin:

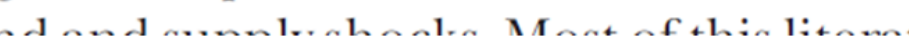

- Drawing Markups

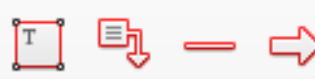

$0 \bigcirc \sqrt{6} \otimes$

\section{How to use it}

- Click on one of the shapes in the Drawing Markups section.

- Click on the proof at the relevant point and draw the selected shape with the cursor.

- To add a comment to the drawn shape, move the cursor over the shape until an arrowhead appears.

- Double click on the shape and type any text in the red box that appears.
7. Drawing Markups Tools - for drawing shapes, lines and freeform annotations on proofs and commenting on these marks.

Allows shapes, lines and freeform annotations to be drawn on proofs and for comment to be made on these marks.

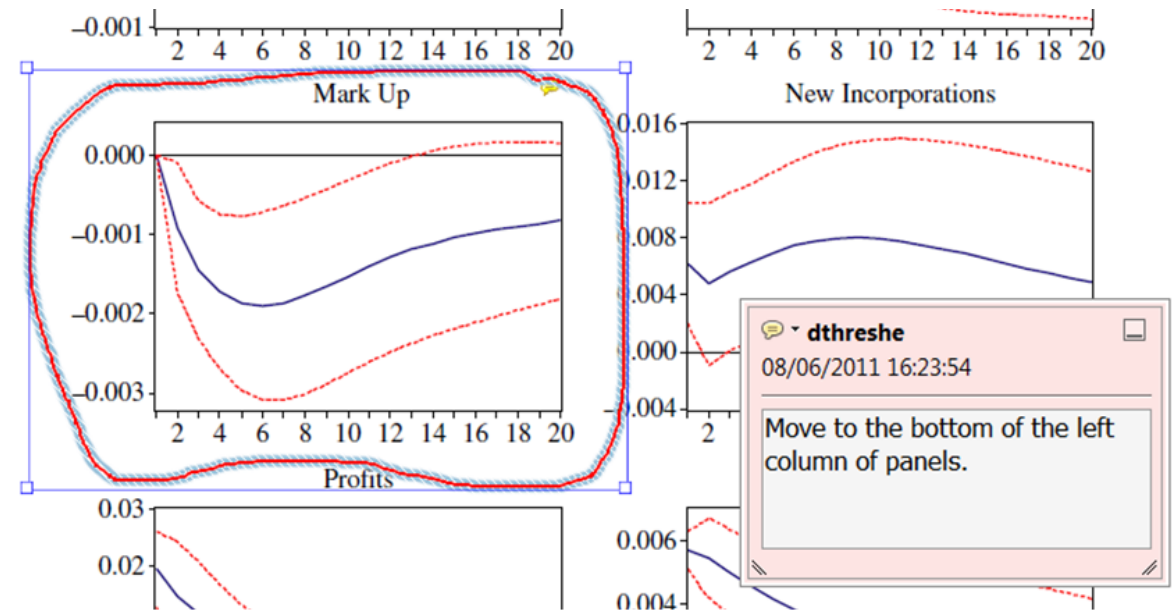

For further information on how to annotate proofs, click on the Help menu to reveal a list of further options:

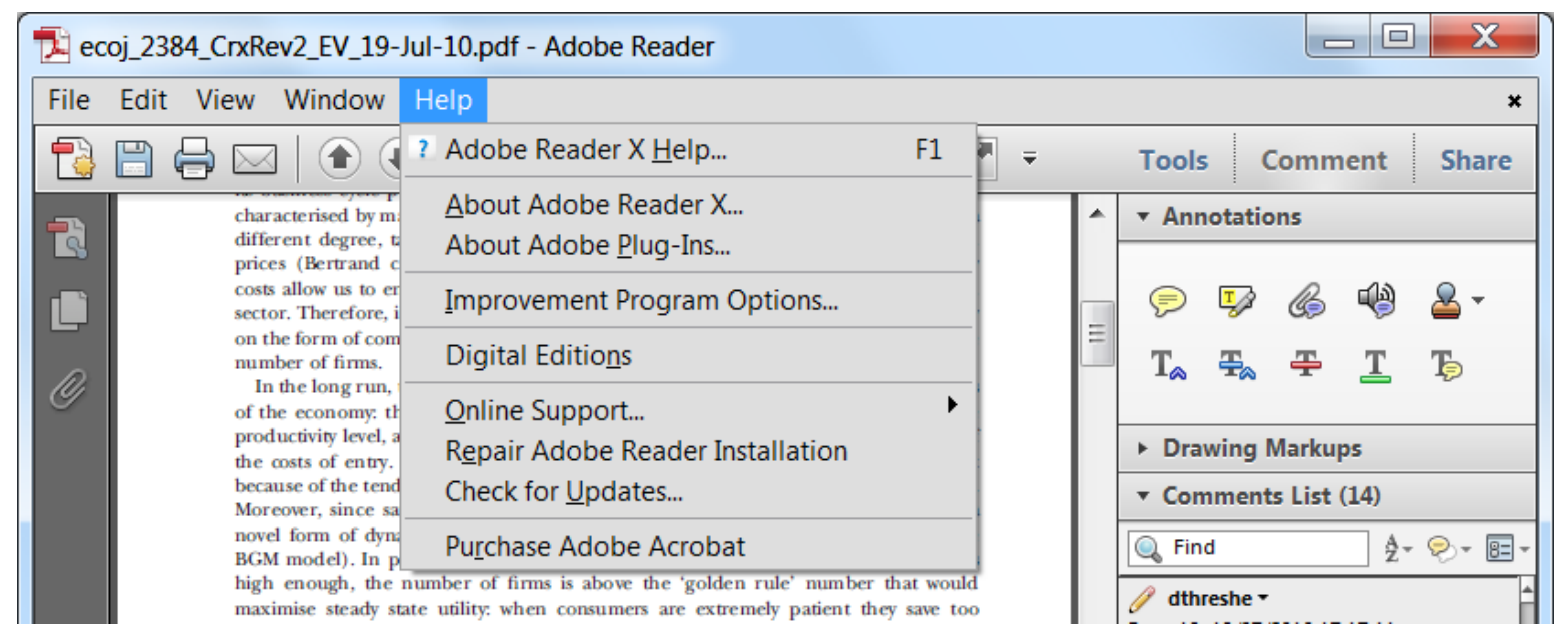

